\title{
Soya küspesinin formaldehit ve kan ile muamelesinin rumende parçalanma özellikleri ve etkin yıkılabilirliği üzerine etkisi*
}

\author{
Sakine YALÇIN ${ }^{1}$, Adnan ŞEHU ${ }^{1}$, Fatma OĞUZ ${ }^{2}$, Numan OĞUZ ${ }^{2}$ \\ Ankara Üniversitesi, Veteriner Fakuiltesi. Hayvan Besleme ve Beslenme Hastalıkları Anabilim Dalı, Ankarat: ?Akdeniz C̈niversitesı \\ Veteriner Fakültesi. Hayvan Besteme ve Bestenme Hastalıkları Anabilim Dalı, Burdur
}

\begin{abstract}
Özet: Arașturmal, soya küspesinin formaldehit ve kan ile muamele edilmesinin kuru madde (KM). organik madide (OM) ve ham protcinin (HP) rumende parçalanma özellikleri ve eckin yıkılabilirliği ïzerine etkisini belirlemek amaclyla yapıllmıșir. Soyi kuispesine formaldehit $0.8 \mathrm{~g} / \mathrm{l}(0) \mathrm{g} \mathrm{HP}$, kan ise $0.5,0.75 .1 .5$ ve $2.0 \mathrm{l} / \mathrm{kg} \mathrm{KM}$ düzeyinde katulmışur. Araşurmada rumen fistiillii 3 bas crğill Mcrinos koçu kullanıımıştır. Numuneler 2.4.8. 16. 24 ve 48 saat sürcyle rumende inkübasyona tabi tululmuşuır. Soya kuispesi numunclerinin rumende KM. OM ve HP parçalanma özellikleri ile ctkin ylkılabilirlikleri belirlenmiştir. Soyat kuispesi proteininin miksimum potansiyel yıkılma degeri, formaldchit ile muameleden etkilenmezken, kan ile muameleden \%2.18 - 10.31 dijzeylerinde azalmışır. Soya kuspesinin $0.8 \mathrm{~g} / 100 \mathrm{~g} \mathrm{HP}$ diuzeyinde formaldehit ve 0.5 . 1.5 ve $2.0 \mathrm{l} / \mathrm{kg} \mathrm{KM}$ düzeylerinde kan ile muamele edilmesi KM. OM ve HP’nin rumende yıkılma hızını artturınıştr. Soya küspesi haun proteinin rumende etkin yıkılmaı değeri $k=$

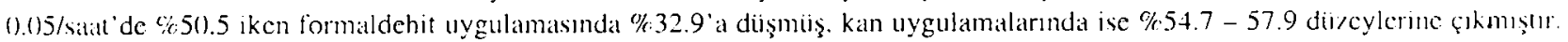
Sonuç olarak. soya kïspesinin formaldehit ile muatmelesinin ruminantlar için ctkili olabileceği kan ile muamele edilmesinin sse rumen fermentasyonundan koruma săglayamadı ğ saptanmışur.
\end{abstract}

Anahtar kelimeler: Formaldehit, kan. korunmus protein, rumende parçalanma ïzcllikleri. soya küspesi

The effect of formaldehyde and blood treatments of soyabean meal on the degradation characteristics and effective degradability in rumen.

Summary: This experiment was carricd out to evaluate the effects of formaldehyde and blood treatments of soyatheall meal on the degradation characteristics and effective degradability of dry matter (DM), orgatnic inatter (OM) and crude protein (CP) in rumen. Soyabean meal treated with $0.8 \mathrm{~g}$ formaldehyde/100 $\mathrm{g} \mathrm{CP} ;(0.5,0.75 .1 .5$ and $2.01 \mathrm{l}$ wolc blood $/ \mathrm{kg}$ DM. Three adult rumen fistulated Merino rams were used in this study. Samples were incubated in the rumen for 2. 4. 8. 16. 24 and $48 \mathrm{~h}$. Rumen degradability characteristics and effective degradability values of DM. OM and CP of soyabean meal simples were determined. Maximum potential degradability values of protein in rumen was not affected by formaldehyde treatment but was decrealsed by 2.19

10. $31 \%$ by blood treatment. Formaldehyde treatment at the level of $0.8 \mathrm{~g} / 100 \mathrm{~g} \mathrm{CP}$ and blood treatment at the levels of 0.5 . 1.5 and 2.) $\mathrm{l} / \mathrm{kg}$ D.M increased the degradition rate constant of soyabcan meal in rumen. Effective degradability valuc of soyabean meal protein in rumen at $k=0.05 / \mathrm{h}$ was found to be $50.5 \%$. This value reduced $1032.9 \%$ with formaldehyde treatment but increased 10 $54.7-57.9 \%$ with blood treatuncnts. As a conclusion. the formaldehyde treatment of soyabean meal could be effective un ruminatns but hlood treatment was not effective for protection from rumen fermentation.

Key words: Blood. formaldchyde, protected protein, rumen degradation characteristics, soyabean meal

\section{Giriş}

Genç hayvanlarda ve yüksck verimli süt ineklerinde, yem maddelerinin değgerlendjrilmesinin arturılması, ekonomik açıdan önemlidir. Bu amaçla, çeşitli metotlar geliştirilmektcdir. Yağlı tohum küspeleri gibi kaliteli protein kaynaklarınm 1sı $(23,32)$, formaldehit $(21,23,35,36)$, tannik asit $(13.23,34)$, kan $(21,26.35,36)$ ve lignosülfonat (19) ile muamele edilmesi proteinin rumende fermentasyontınu azaluığından verimi olumlu yönde etkilemektedir $(11,31,33)$.

Yağlı tohum küspelerinin $1.1 \mathrm{~g} / 100 \mathrm{~g}$ ham protein (HP) düzeyinde formaldehit ile muamelesi, rumende pro- tein y1kılabilirliğini; ayçiçeğ küspesinde $80^{\prime} \mathrm{den} \% 15^{\prime} \mathrm{e}$, kolza küspesinde ise \%72'den \% 19'a duişuirmiişiur (14)

Bazı araşurıcılar $(2.27 .29)$ soya küspesinin formaldehit ile muamelesinin rumende protein çöəünebilirliğ ğinj veya rumende amonyak birikimini diişürdịğinin kaydetmişlerdir.

Thomas ve ark. (32), soya kiispesinin 0.4.0.6 ve 0.81 $100 \mathrm{~g}$ HP düzeylerinde formaldehit ile nuamelesinin, bağırsaklardaki yararlanılabilirliği azalımadan rumende ham proteinin yıkılabilirliğini önemli ölçüide diişüirdïğ̆uinii bildirmişlerdir. 
Deniz ve Tuncer (12), soya küspesinin formakichit (0.3. 0.6. 0.9.1.2 $\mathrm{g} / 100 \mathrm{~g} \mathrm{HP})$ ile muamele edilmesinin rumende kuru madde (KM). HP ve etkin protcin yıkılabilirliği üzerine etkisini araştırmışlar ve kullanılan formaldehit dïzeyine bağlı olarak KM ve HP yıkılabilirliğ ile ctkin protein yık1labilirliğinde azalma meydana geldiğgnin gözlemişlerdir $(p<0.01)$.

Ørskov ve ark. (26), soya küspesi (SK) ve yer fıstığı küspesinin $0.25,0.50,1.00,1.50 \mathrm{ve} 3.00 \mathrm{l} / \mathrm{kg}$ düzeyinde kan ile muamele edildiğinde rumende 4 ve 8 . saatlerdeki a7.o1 yıkılabilirliğinin azaldığım bildirmişlerdir.

Yalçın ve ark. (36), ayçiçeği küspesinin formaldehit ve kan ile nuamele edilmesinin KM, organik madde (OM) ve HP'nin rumende parçalanma özellikleri ve etkin yıkılabilirliği ìzerine etkisini araştırmışlardır. Ayçiçeği küspesinin $0.8 \mathrm{~g} / 100 \mathrm{~g} \mathrm{HP}$ düzeyinde formaldehit ile muamelesi. proteinin rumende kolay çözünebilen miktarmı. yıkılma hiz sabitini ve etkin y1kılabilirliğini s1rassyla \% $75.36,22.70$ ve 20.89 dü\%eyinde azaltmıs. fakat zamanla yıkılahilen miktarm \%19.57 düzeyinde arturarak maksimum potansiyel yıkılabilirliğini ctkilememişir. Küspenin 2 l/kg KM düzeyinde kan ile muamele edilnesi ise proteinin yıklma h1\% sabitini ve etkin y1kılabilirliğini strası ile $\% 39.40$ ve 24.84 düzeyinde azaltmuşıır.

Bu araştırma. soya kuispesinin formaldehit ve farklı düzeylerde kan ile muamele edilmesinin $\mathrm{KM}, \mathrm{OM}$ ve HP'nin rumende parçalanma özellikleri ile etkin y1kılabilirlikleri iizerine etkisini belirlemek amacıyla yapılmışır.

\section{Materyal ve Metot}

\section{Soya küspesinin formaldehit ile muamelesi}

Kuispeye katılacak formaldehit düzeyi. küspedeki HP'nin \%0.8'i olacak şekilde hesaplanmışır $(12,15)$. Gerekli olan formaldehit, bir kap içcrisine koyulmuş ve üzerine muamele edilecek küspe ağ ıılmışur.

Formaldehit-su kanışımı küspe üzerine puiskürtülcrek iyi hir şckilde karışırıılmıştır. Hava geçirmeyen plastik torbalarda 48 saat bekletildikten sonra tepsilere ince bir şekilde yayılarak oda sicaklığında kurumaya bırakılnıışırı (32).

\section{Soya küspesinin kan ile muamelesi}

Sodyum sitrat kapsayan ( $6.8 \mathrm{~g} / \mathrm{l} \mathrm{kan)}$ taze sığı kanı $0.5,0.75,1.5$ ve $2.0 \mathrm{l} / \mathrm{kg} \mathrm{KM}$ düreyinde olacak şekilde kuispeye puiskuirtülerek kanışırılmıştır. Tam bir karışım sağlandiktan sonra tepsilere ince bir şckilde yayılarak $60^{\circ} \mathrm{C}$ 'de hava akımlı etüv'de kurutulnuştur (21).

\section{Küspe numunelerinin rumende parçalanma özellikleri} ve etkin yıkılabilirliklerinin belirlenmesi

Bu amaçla, ortalama $60 \mathrm{~kg}$ canlı ağırlığında olın ve rumen kanülü takılmış 3 baş ergin Merinos ırkı koç kullanılmışur. Hayvanlara günde $200 \mathrm{~g}$ konsantre yem $(\% 50$ arpa, \%25 ayçiçę̆ küispesi. \%21 buğday kepeği, \%1 tuz., $\% 1$ dikalsiyum fosfat, \%1 kireç taşı, \%1 vitamin-mineral karması*) ve 900 g yonca kuru otu iki öğüunde verjlmiştir. Rumen inkübasyonu için SK nummesi. formaldehit ve farklı düzeylerde kan ile muamele edilmiş SK numuneleri kullanılmışır.

Yem maddelerinin rumendeki KM kayıplan $\varnothing$ rskov ve ark. (24) tarafından naylon kese tekniği kullanılarak belirlenmiştir. Araşurmada, Ørskov ve ark. (24) tarafından belirtilen özelliktc, por genişliğ $20-40 \mu \mathrm{m} \mathrm{ve}$ boyutları $9 \times 14 \mathrm{~cm}$ olan naylon keseler kullanılmı̧̧ır. Küspe numuncleri por genişliği $5 \mathrm{~mm}$ olan eleklen gِcçirilerek nunune partikuil biiyuikliiğüunuin yaklaşık $3 \mathrm{~mm}$ olması sağglanmıştır. Numunclerden 5 g tartularak darası belli olan naylon keselere koyulmuştur. Naylon keselerin ağ 21 bir lastik ilc sikıca bağ lanarak $25 \mathrm{crn}$ uzunluğundaki plastik hortuma tutturulnuş ve kaniilden rumen içerisine sarkıtılmıştır. Hortumların uçları kaniil kapağ̊na tulturularak inkuibasyon süresince tıpası kapalı tutulmuştur. Numuneler 2, 4, 8, 16, 24 ve 48 sallik suircyle rumende inkübasyona tabi tutulmuşur. Her bir numune ve her bir inkübasyon süresi için 3 paralelli çalışılmışır. Inkiihas yon süresi sonunda. plastik hortumlara bağlanmıs olan naylon keseler rumenden alınarak mikrobiyel aktivitenin durması için hemen soğuk suya daldırılmışur. Daha sonra keseler akan su altunda tutulan bir kova içinde su berraklaşıncaya kadar çalkalanmıştır. Keseler $60^{\circ} \mathrm{C}$ 'deki ctiivde sabil ağırlığa ulaşıncaya kadar (yaklaşık 48 saat) bekletilerek kurutulmuşrur.

Naylon kescler soğgduktan sonra tartlarak K.M kil yıplanı (\%) bulunmuştur. Rumende parçalanma (\%)ellikleri $p=a+b\left(1-c^{-l}\right)$ eşilliğinden yararlanılarak (25) sap. tanmıştır. Bu denklende $\mathrm{p}=1$ zamanında yem KM $y_{1-}$ kılabilirliğini, $a=$ kolay çözüncbilen yen KM miklarm. $\mathrm{b}=$ çörünmeyen fakat zamanla yıkılabilen yem KM miktarını. $\mathrm{c}=$ yemin $\mathrm{KM}$ yıkılma hı\% sabiini, $\mathrm{l}=$ zamanı (saat) göstermektedir. Yem maddelerinin salatlere gore OM ve HP yıkılabilirlikleri ile rumende parçallanma ibel. likleri de belirlenmiştir (25).

Ycm maddelerinin KM, OM ve HP etkin yikslabilirlikleri de $\mathrm{P}_{\mathrm{c}}=\mathrm{a}+(\mathrm{bc}) /(\mathrm{k}+\mathrm{c})$ formülü kullaniarak hesaplanmışur (25). Burada $P_{c}=$ besin maddesinin etkin $y_{1-}$ kılabilirliğ $\mathrm{i}, \mathrm{k}=$ besin maddesinin rumenden çıkıs hızını göstermektc, a. b ve c ise yukarıda açıklandığ şekildedir. Etkin ytkılabilirliğin hesaplanmasında $k$ degeri 0.02 .0 .05 ve $0.08 /$ saat olarak alınmışır.

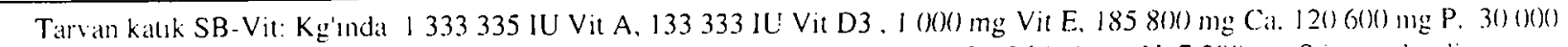

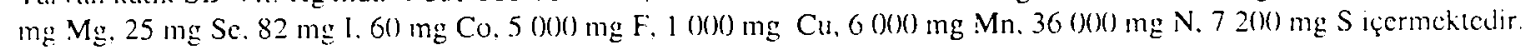




\section{Kimyasal analizler}

Hayvanların beslenmesinde kullanilan yemlerde, muante edilmiş ve edilmemiş SK'da ham besin madde analizleri, inkübasyondan sonra naylon keselerde kalan mumunelerde KM. OM ve HP analizleri AOAC' de (3) belirtilen metotlar ile gerçekleştirilmiştir.

\section{Istatistik analizler}

Yen maddelerinin rumenden parçalanma özclliklcri Orskov ve McDonald'ın (25) geliştirdikleri $p=a+b\left(1-e^{-c t}\right)$ eksponensiycl denklemine göre, Naway bilgisayar programından yararlanılarak bulunnuş̧ur.

\section{Bulgular}

Araştırmada kullamılan SK, yonca kuru otu ve konsantre yemin kimyasal bileşimi Tablo l'de verilmiştir. Deneme ycmleri KM. OM ve HP'nin rumende parçalanma özellikleri ve etkin yıkılabilirlikleri Tablo 2 'de göste- rilmiştir. Deneme yemleri HP'nin saatlere göre rumende yıkılabilirlik eğrileri ise Şekil l'de verilmiştir.

Muamele görmemiş SK'nun KM, OM ve HP'nin maksimum potansiyel yıkılabilirlik değerleri $(a+b)$ sırası ile \%91.10.91.68 ve 92.03 olarak bulunmuştur. Soya küspesi HP'nin rumende etkin yıkılma değeri $k=0.05 /$ satat'de $\% 50.5$ iken formaldehit uygulamasında $\% 32.9^{\circ}$ a dỉşmüs. kan uygulamalarında ise \%54.7-57.9 diizeylerine çımiştır.

\section{Tartışma ve Sonuç}

Soya küspesinin KM, OM ve IIP yıkama kayıplar sirasiyla \%25.70, 25.00 ve [8.11 olarak bulunmuştu]. Sonuçlar baz.ı araşurıcıların $(10,18,34)$ bulgularından diişiiktuir. Yapılan araşırmada SK yıkama kaybının formaldkhit ile muamelesinde azaldığ lığı görülmüştür.

Tablo I. Araşurmada kullanılan yenılerin kimyasal bileșimleri, \%. *

Table 1. Chemical composition of feeds used in the experiment, $\%$.

\begin{tabular}{lcccccc}
\hline $\begin{array}{l}\text { Ycm } \\
\text { makldesi }\end{array}$ & $\begin{array}{c}\text { Kuru } \\
\text { madde }\end{array}$ & $\begin{array}{c}\text { Organik } \\
\text { maddic }\end{array}$ & $\begin{array}{c}\text { Ham } \\
\text { protcin }\end{array}$ & $\begin{array}{c}\text { Ham } \\
\text { seluiloz }\end{array}$ & $\begin{array}{c}\text { Ham } \\
\text { yag }\end{array}$ & $\begin{array}{c}\text { Azotvi\% } 0 \% \\
\text { madde }\end{array}$ \\
\hline Soya kïspesi & 90.97 & 92.80 & 49.91 & 8.20 & 1.77 & 32.92 \\
Yoncal kuru oul & 91.67 & 90.07 & 12.32 & 26.94 & 1.62 & 49.19 \\
Konsantre ycm & $9(1.65$ & 93.13 & 19.37 & 11.27 & 1.90 & 60.59 \\
\hline
\end{tabular}

* : Değerler kuru madde csilsına göre verilmiştir.

Tablo 2. Deneme yemlerinde kuru madde, organik madde ve ham proteinin rumende parçalanma özellikleri ve ctkin yikilmat deşer leri Table 2. The rumen degradability characteristics and effective degradability values of dry matter. organic matter and crude protein of experimental feeds.

\begin{tabular}{|c|c|c|c|c|c|c|c|c|c|c|c|c|}
\hline \multirow{2}{*}{$\begin{array}{l}\text { Yem } \\
\text { maddesi }\end{array}$} & \multirow{2}{*}{$\begin{array}{l}\text { Yikama } \\
\text { kaybl }\end{array}$} & \multicolumn{3}{|c|}{ Inkuibasyon süresi. saat } & \multirow{2}{*}{ a } & \multirow{2}{*}{ b } & \multirow{2}{*}{$\begin{array}{c}\mathrm{c} \\
\text { fraksiy/sa }\end{array}$} & \multirow{2}{*}{$\begin{array}{c}a+b \\
\%\end{array}$} & \multirow{2}{*}{$\begin{array}{l}\text { Res std } \\
\text { sapmil, \% }\end{array}$} & \multicolumn{3}{|c|}{$P_{L} \%$} \\
\hline & & 2 & 24 & 48 & & & & & & $0.02 / \mathrm{sa}$ & $0.05 / \mathrm{sat}$ & $0.08 / \mathrm{sil}$ \\
\hline \multicolumn{13}{|l|}{ Kuru maddc } \\
\hline SK & 25.70 & 26.06 & 67.85 & 84.90 & 22.62 & 68.48 & 0.0481 & 91.10 & 2.75 & 71.0 & 56.2 & 48.3 \\
\hline SKOYXFORM & 20.90 & 22.63 & 45.31 & 59.78 & 21.24 & 76.19 & 0.0148 & 97.43 & 1.61 & 53.6 & 38.6 & 33.1 \\
\hline SK $0.5 K \wedge N$ & 35.4() & 37.44 & 69.46 & 80.36 & 32.30 & 55.17 & 0.0436 & 87.47 & 1.17 & 70.1 & 58.0 & 51.8 \\
\hline$S K_{11} 75 \mathrm{KAN}$ & 37.85 & 38.74 & 73.73 & 80.87 & 31.68 & 55.89 & $(0.0480$ & 87.57 & $3.1) 2$ & $7 ! .1$ & 59.1 & 52.6 \\
\hline $\mathrm{SK}_{1.5 \mathrm{KAN}}$ & 37.60 & $+(1) .41$ & 65.63 & 80.53 & 37.09 & 55.20 & 0.0318 & 92.29 & 0.79 & 71.0 & 58.6 & 52.8 \\
\hline $\mathrm{SK}_{2 \mathrm{~K} A N}$ & 40.82 & 44.63 & 65.96 & 78.35 & 42.19 & 49.58 & 0.01272 & 91.77 & 0.18 & 70.8 & 59.7 & 54.8 \\
\hline \multicolumn{13}{|c|}{ Organik maddc } \\
\hline Sk & 25.00 & 24.43 & 66.70 & 84.50 & 20.84 & 70.84 & 0.0462 & 91.68 & 2.64 & 70.3 & 54.9 & 46.8 \\
\hline SKO.SI:ORM & 20.40 & 20.72 & 43.36 & 59.19 & 18.44 & 81.56 & 0.0143 & 100.00 & 1.44 & 52.4 & 36.6 & 30.8 \\
\hline SK0.5KAN & 35.54 & 36.80 & 68.57 & 80.60 & $31.7 !$ & 57.91 & 0.0395 & 89.62 & 1.14 & 70.2 & 57.3 & .50 .9 \\
\hline $\mathrm{SK}_{(1)} \geq 5 \mathrm{~K}+\mathrm{V}$ & 37.04 & 37.63 & 73.35 & 78.36 & 30.00 & 53.80 & 0.0538 & 83.80 & 3.4() & 69.2 & 57.9 & 51.6 \\
\hline$S K_{I .5 K S N}$ & $37.41)$ & 39.53 & 65.55 & $80.60)$ & 36.16 & 57.29 & 0.03() 9 & 93.45 & 0.52 & 71.0 & 58.1 & 52.1 \\
\hline $\mathrm{SK}_{2 \mathrm{~K} A N}$ & 40.49 & 43.91 & 65.70 & 78.52 & 41.49 & 52.05 & 0.0259 & 93.54 & 0.38 & 70.9 & 59.3 & 54.2 \\
\hline \multicolumn{13}{|l|}{ Ham prolcin } \\
\hline SK & 18.11 & 16.99 & 65.46 & 83.66 & 11.58 & 80.45 & 0.0469 & 92.03 & 2.68 & 68.0 & .50 .5 & 41.3 \\
\hline$S K_{11,81: O R M}$ & 14.28 & 13.80 & 40.85 & 56.41 & 13.35 & 80.62 & 0.0160 & 93.97 & 2.99 & 49.2 & 32.9 & 26.8 \\
\hline SKO.SKAN & 33.68 & 34.85 & 65.73 & 77.19 & 29.97 & 55.92 & 0.0396 & 85.89 & 1.12 & 67.1 & 54.7 & 48.5 \\
\hline$S K_{1}-5 K A X$ & 34.72 & 32.89 & 71.52 & 78.32 & 27.03 & 55.51 & 0.0577 & 82.54 & 2.30 & 68.3 & 56.8 & 50.3 \\
\hline SKJ.5KAN & 36.69 & 39.18 & 63.87 & 78.77 & 36.49 & 53.53 & 0.0319 & 90.02 & 1.07 & 69.4 & 57.4 & 51.8 \\
\hline$S K_{2 K A N}$ & 40.09 & 43.78 & 63.37 & 74.93 & 42.54 & 46.70 & 0.0245 & 89.24 & 1.06 & 68.3 & 57.9 & 5.3 .5 \\
\hline
\end{tabular}

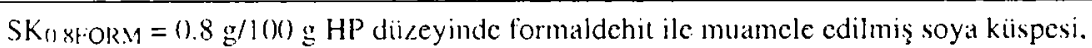

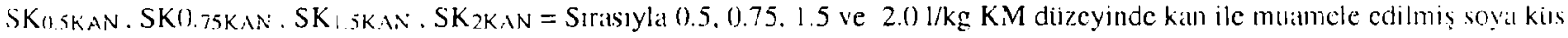
pesi 


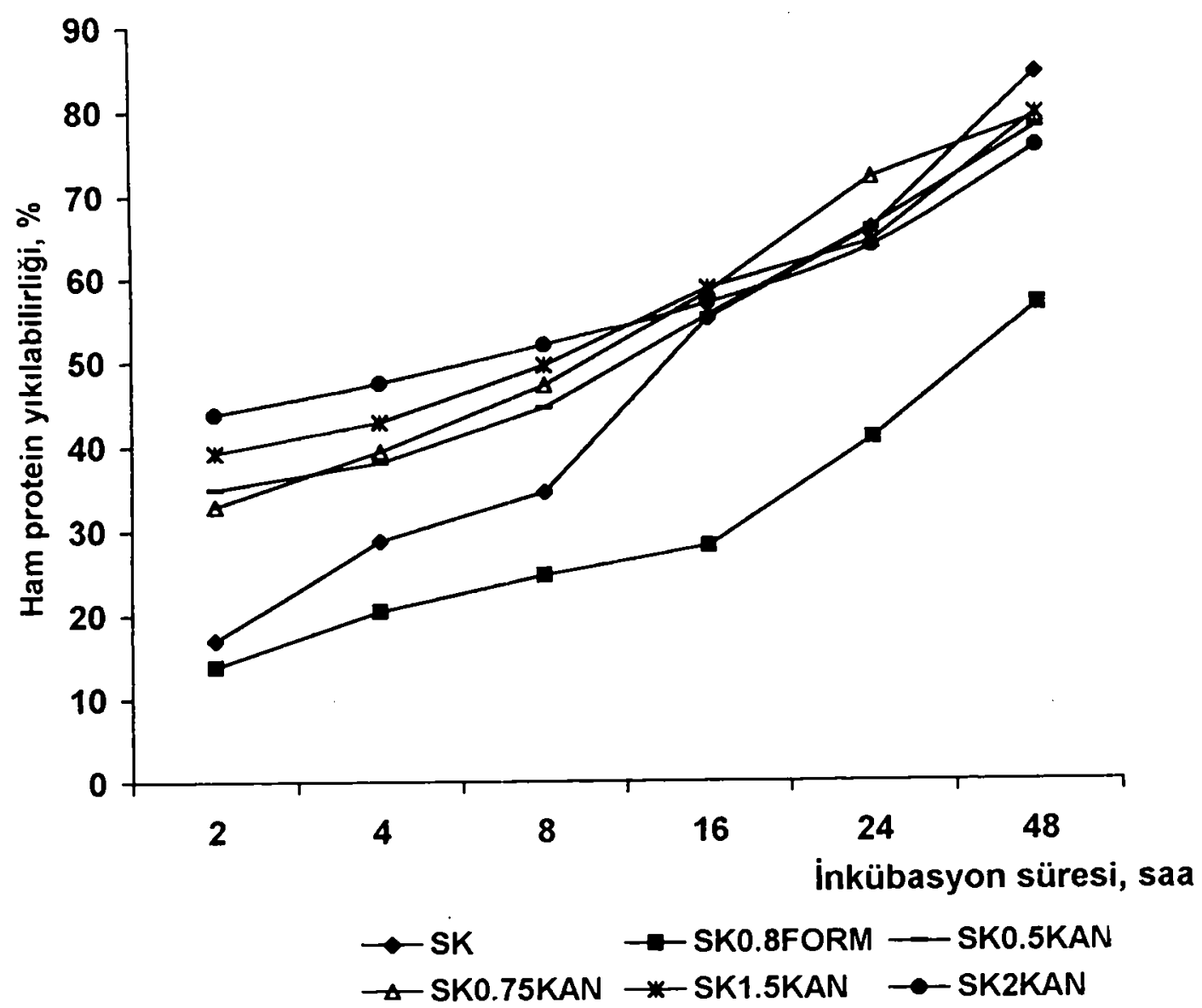

Şekil 1. Deneme yemlerinin rumende HP yikılabilirlik e⿻̆e risi

Figure 1. The rumen CP degridability curves of experimental fecds

(SK0).8FORM $=0.8 \mathrm{~g} / 1(0) \mathrm{g}$ HP düzeyinde formaldehit ile muamele edilmiş soya küspesi. SK(1).5K AN SK0.75KAN . SK1.5KAN. SK2KAN = Strastyla (0.5. (0.75. 1.5 ve $21 / \mathrm{kg} \mathrm{KM}$ düzeyinde kan ile muancle cdilmiş soyal kijspesi)

Muancle edilmemis SK'nın 2 saatlik rumen inkübasyonu sonunda rumende KM'nin yıkılan miktarı \% 26.06 iken, 24 saatte $\% 67.85^{\prime} \mathrm{c}, 48$ saatte $\% 84.90^{\prime}$ a yüksclmiştir (Tablo 2). SK'nun rumende 48 saat sonundaki KM. OM ve HP yıkılma oranı sirasiyla \% $84.90,84.50$ ve 83.66 olarak bulunmuştur. Bu değerlerden SK'nın rumende yüksek düzeyde yıkıldığ anlaşılmaktadır. Küspenin 2 saatlik rumen inkübasyonu sonunda yıkılan KM ve HP miktarı bazı araşırıcıların $(9,17,20)$ bulgularından düşïkıuir. Yalçın ve ark. (34) ise, yapılan araştırma bulgusuna benzer olarak rumende 2 saatte yikılan HP miktarım \%.17.39 bulmuşlardır. Yılmaz. (37), incelediği 12 adcl SK numunesinde rumende 48 saat sonundaki KM ve OM yikılma oranlarimin sirasiyla \%74.55-98.54 ve $\%$ 75.61-98.61 arasında olduğunu bildirmiştir. Yapılan arașinma bulgulan Yılma\%”n (37) bulduğ değerler ile uyum içerisindedir. Buna karşllık. araştırma bulgular håı araştrrıcılarm $(1,10,12.28) 24$ ve 48 saat sonunda belirledikleri KM, OM ve HP yıkılma oranlarından düşüktuir. I itcraluirler arasındaki bu farklılıklar küspenin üretim teknolojisinden özellikle uygulanan 1sı düzeyinden kaynaklanabilir. Soya küspesinin farklı düzeylerde kan ile muamelesi. KM, OM ve HP yikama kaybinın \%35-121, rumende ilk 2 saatte yıkılan KM, OM ve HP oranmın ise \%43-157 düzeylerinde artmasına yol açmışır. Küspenin $0.8 \mathrm{~g} / 100 \mathrm{~g}$ HP düzcyinde formaldehit ile muanclesi ise KM. OM ve HP yikama kaybinda \%18-21 dizeyinde a7almaya neden olmuştur. Aynı şckilde, rumende 2. $24 \mathrm{ve}$ 48 saatlerde yıkılan KM. OM ve HP'de de azalnıa olduğ Tablo 2'de göruilmektedir. Araştırma bulgulan Deniz ve Tuncer'in (12) SK'nın 0.3, 0.6.0.9 ve $1.2 / 100$ g HP diizcylerinde formaldehit ile muamelesinin rumende 24 saatlik inkübasyon sonucu KM ve HP y1kılmmonda il\%almaya neden olduğu şeklindeki bulgularıyla henzerlik göster mektedir.

Rumende kolay çözinebilen KM. OM ve HP mik tarları işlem görmemiş SK için sırasıyla \% 22.62, $20.84 \mathrm{ve}$ 11.58 olarak hesaplanmışur. Sonuçlar bazı araştırıcuların bulgularına $(1,34,37)$ benzerlik gösterirken bazlanmkinden $(4.6,21,30)$ farkiılık arzelmekledir. Yapılan ataş urmada, SK daki KM ve OM'nin rumende kolay f̧örüne bilen niktarmun formaldehit uygulamasi ile aralıtken. kan ile muamelede artığ̆ gözlenniș̣tir. Soya küspesi HP'nin rumende kolay çözünebilen miktan lomaldehit ile muamelesiyle $\% 15$, farklı dizeylerde kan ile muame lesiyle \%133-267 düzeylerinde artmıştır. Benzer olarak, 
rumende kolay çözünebilen HP miktarının, fındık küspesi ve ayçiçeği küspesinin $0.5 .0 .75,1.5$ ve $2.0 \mathrm{l} / \mathrm{kg} \mathrm{KM}$ dü7.eylerinde kan ilc muamelesiyle arttı̆̆ $(35,36)$, buna karşlık SK ve kanola küispesinin $0.75,1.5$ ve $2.01 / \mathrm{kg}$ küspe diuzeylerinde kan ile muamelesiyle azaldığ (21) kaydedilmiştir. Araşurma bulgularına benzer olarak, $0.8 \mathrm{~g} /$ 100 g HP düzeyinde formaldehit ile işlenen bazı yağlı tohum küspelerinin rumende kolay çözünebilen HP mik tarında azalmanın olduğu da rapor edilmiştir (21).

Soya küspesinin rumende çözünmeyen fakat zamanla yıkılabilen KM. OM ve HP degecrleri sirasiyla \%68.48, 70.84 ve 80.45 olarak bulunmuştur (Tablo 2). Sonuçlar bazı araştımcılarm bulgularına $(1,37)$ benzerlik göslerirken bazılarınkinden $(4,6,21)$ farklılık göstcrmektedir.

Soya küspesinin formaldehit ile nuamelesi rumende çozüunneyen fakat zamanla yıkılabilen KM ve OM miktarm arturırken. HP mikıarın etkilememiştir. Soya küspesinin farkli düzeylerde kan ile muanelesi ise, rumende çözümmeyen takat zamanla yıkılabilen KM, OM ve HP mikıarmın \% 18.25-41.95 düzeyinde azalmasına yol açmışur (Tablo 2). Bulgular, bazı araştırıcıların bazı yağlı tohum küspelerinin formaldehit $(21,35)$ ve kan $(21,35.36)$ ile muamelesinin rumende HP'nin zamanla yıkılabilen niklarını azaltı̆̆g şeklindeki bildirişleriyle uyuşmaktadır.

Soya küspesinin KM, OM ve HP maksimum polansiyel yıkılma $(\mathrm{a}+\mathrm{b})$ değerleri sırasıyla $\% 91.10,91.68$ ve 92.03 olarak bulunmuştur. Sonuçlar, Yılmaz'ın (37) 12 adeı SK için belirlediği ' $a+b$ ' değgerleri ile uyum içerisindedir. Buna karşılık araştırna sonuçları, bazı araşImcılarn $(1,34)$ bulgularından düşük, Stanford ve ark. (30)'nın bildirdiğ SK'nun formaldehit ile muamelesi, rumende $\mathrm{KM}$ ve OM'nin maksinum polansiyel yıkılma değerini \%6.95 düzeyinde artırırken, HP'nin ' $a+b$ ' değerini etkilememiştir. Soya küspesindeki HP'nin ' $a+b$ ' değcri farklı düzeylerde kan ile muameleden \%2.18-10.31 duizeyinde ayalmuştır. Mir ve ark. (21) ise, SK ve kanola küspesinin ayn düzcylerde formaldehit veya kan ile işlenmesinin, rumende HP'nin maksimum potansiyel yıkılabilirliğini azaltı̆ğın bildirmişlerdir.

Muamele görmemiş $S K$ proteininin rumende y1kılma hız sabiti 0.0469 /saat olarak tespit edilmiştir. Sonuçlar bazı araştırıcıların $(1,21,34,37)$ bulgularına benzerlik gösterirken, bazılarmın $(4,6,28)$ belirlediği değerlerden farklılık göstcrnektedir. Bu farklılık küspenin ürelim teknolojisine bağlanabilir. Kuispenin $0.8 \mathrm{~g} / 100 \mathrm{~g} \mathrm{HP}$ dïzyinde formaldehil ve $0.5,1.5$ ve $2.01 / \mathrm{kg} \mathrm{KM}$ diizeyinde kan ile muamele edilmesi KM, OM ve HP'nin rumende yıkılma hızını azalınıştır. Benzer olarak, AÇK'nın 1.5 ve $2.0 \mathrm{l} / \mathrm{kg} \mathrm{KM}$ düzeyinde kan ile muamelesi HP'nin rumende yıkılma hızını azaltığı kaydedilmiştir (36).

Soya küspesinin rumende etkin yıkılma değeri $\mathrm{k}=$ 0.02 / saat'de KM, OM ve HP için sirasiyla \%71.0, 7().3 ve 68.0 olarak bulunmuştur. Bulgular bazı araştıncıların $(34,37)$ bulgularına benzerlik gösterirken bazı araş- tırıcıların $(1,8,10,12,22,30)$ bulgularından diişuiktür. Soya küspesi HP'nin rumende etkin yıkılma değeri $\mathrm{k}=0.05 /$ saat'de $\% 50.5 \mathrm{iken}$ formaldehit uygulamasinda $\% 32.9^{\circ}$ a düşmüş, kan uygulamalarnda ise $\% 54.757 .9$ diizeylerine çıkmıştır. Mir ve ark. (21), SK ve kanola küspesinin ayı1 düzeylerde formaldehit ve kan ile muamelesinin $\mathrm{k}=0.05$ / saat çıkıs hızında proteinin etkin yıkılabilirliğinin istatistiki açıdan önemli derecede $(p<0.05)$ akalmasına neden olduğunu kaydetmişlerdir. Araştırma bulgularma benzer olarak Deniz ve Tuncer (12), SK'nın formaldehil ile nuamelede etkin protein ylkılabilirliğinin islatistik açıdan önemli derecede acaldı ğını bildirmişlerdir.

Literatürler arasindaki farklılıklar: küspe örnckleri arasındaki farklılıktan, metor farklılığından. hayvanlat arasındaki farklılıktan, örneklerin partikiil biiyijklïğiinden, küspe işleme tekniğindeki farklılıktan. rasyondiaki konsantre yem düzeyinden ve rasyondaki ham prolein miktarmdan kaynaklanabilir $(5,7,14,16.30)$.

Yapılan araşırmada, işlem görmeniş $S K$ ya kıyasla. formaldehit ile muamelede 24 ve 48 saat inkibasyon sonunda rumende yıkılan KM, OM ve HP miktarmnn dïşiik olmasina rağmen rumende çözünmeyen fakat zamanlat y1kılan değcrin yüiksck ve yıkılma hız sabitininde çok düşü olması asimptot değcrine 48 saatte ulaşlmadığn göstermektedir (Tablo 2 ve Şekil 1). Bu durum, küispenin rumende maksimum potansiyel yıkılabilirliğinin formaldehit muamelesi ile arttığını göstermektedir. Bununla birlikte, küspede rumenden farklı çıkıs hızlarında eıkin y!kılabilirliğinin azalması küspenin $0.8 \mathrm{~g} / 100 \mathrm{~g} \mathrm{HP}$ diizeyinde formaldehit ile muamcle edilmesinin uygun olabileceğini göstermektedir. Ayrıca. rumende yıkılma hız sabitinin çok azalması da çoğunluğunu lignosclülozik yem kaynaklarının oluşturduğu rasyonlarla beslemede rumende azot ve cnerjinin yavaş açığa çıkması etkili bir feermantasyonu da sağlayacakır (1).

Soya küspesinin farklı düzeylerde kan ile muamelesi ise rumende çörünmeyen fakal zamanla yıkılan miktarı azaltsa da kolay çözünebilen miktarı ve rumende clkin yı. kılabilirliği artturması nedeniyle $S K$ 'nın kan ile muamelesinin uygun olmadı. gablo $_{1}$ ve Sckil l'den göruilmektedir.

Sonuç olarak, soya küspesinin $0.8 \mathrm{~g} / 100 \mathrm{~g} \mathrm{HP}$ diizeyinde formaldehit ile muamelesinin ruminantlar için etkili olabileceği, 0.5, 0.75, 1.5, 2.0 l/kg KM diizeyinde kan ile muamele edilmesinin ise rumen fermentasyonundan koruma sağlayamadiğı saptanmıştır.

\section{Kaynaklar}

1. Aguilera JF, Bustos M, Molina E (1992): The desradahility of legume seed meals in the rumen: effect of heat treatment. Anim Feed Sci Tech, 36. 1()1-112.

2. Amos HE, Burdick D, Huber TL (1974): Effects of formaldehyde treatment of sunflower and sorbean meal on nitrogen balance in lambs. J Anim Sci, 38, 702

3. AOAC (1984): Official Methods of Analysis of the Association of Official Analytical Chemists. $14^{\text {th }}$ ed. William Byrd Press Inc. Richmond. Virginiat. 
4. Armentano I,E, Herrington TA, Polan CE, Moe A.J, Herbein JH, Umstadt P'(1986): Ruminal degradation of dried brewers grains, wet brewers grains and soybean meal. J Dairy Sci, 69. 2124-2133.

5. Barrio JR, Goetsch $\mathbf{\Lambda}$, Owens $\mathbf{F N}$ (1986): Effect of dietary concentrate on in situ dry matter and nitrogen disappearance of a variety of feedstuffs. J Dairy Sci, 69.420430 .

6. Batajoo KK, Shaver RD) (1998) In situ dry matter, crude protein and starch degradabilities of selected grains and M-product feeds. Anim Feed Sci Tech, 71. 165-176.

7. Boila R.J. Ingalls JR (1992): In sim rumen digestion and escape of dry matter. nitrogen and amino acids in canola meal. Can J Anim Sci, 72, 891-901.

8. Broderick (;A, Wallace R.J, Ørskov ER, Hansen $\mathbf{I}$ (1988): Comparison of estimates of ruminal protein degradution by in vitro and in situ methods. J Anim Sci, 66 1739-1745

9. Crawford R.J, Hoover WH, Sniffen C.J, Crooker BA (1978): Degradation of feedstuff nitrogen in the rumen is nitrogen solubility in three solvents. J Anim Sci, 46, 17681775.

10. De Boer G, Murphy JJ, Kennelly JJ (1987): A modified method for detemination of in situ rumen degradation of feedstuffs. Can J Anim Sci, 67, 93-102.

11. Deniz S, Coşkun B, Inal F, Şeker E, Iş̧ı K (1993): Formaldehit ile muamele edilen sova fasulyesi küspesinin danalarda canle ağarlik arths ve yemden yararlanma ile baza kun re rumen sivist metaholitleri üzerine etkisi. Hayvancılık Araştırma Derg. 3, 8-11

12. Deniz S, Tuncer \$̧D (1995): Bitkisel protein kaynaklartmun formaldehit ile muamele edilmesinin rumen kuru madde ve. ham protein ile effektif protein ykilumi üzerine etkisi. Turk J Vei Anim Sci, 19.1-8.

13. Driedger A, Hatfield EE (1972): Influence of tamins on the nutritive value of soybean meal for ruminants. J Anim Sci. 34. 465-468.

14. Freer $\mathbf{M}, \mathbf{D o v e} \mathbf{H}$ (1984): Rumen degradation of protein in suinflower meal. rapeseed meal and lupin seed placed in myton bags. Anim Feed Sci Tech. 11, 87-101.

15. Hagemeister H, Lüpping W, Kaufmann W (1981): Microbial Protein Synthesis and Digestion in the High Yielding Daing Con: 31-48. In: W Haresign, DJA Cole (Eds). Recent Advances in Ruminant Nutrition. Butterworths, London.

16. Kirkpatrick BK, Kennelly JS (1987): In situ degradability of protein and dny matter from single protein sources and from a total diet. J Anim Sci, 65, 567-576

17. Lindberg JE, Varvikko T (1982): The effect of bag pore size on the ruminal degradation of diy matter, nitrogenous compounds and cell walls in nylon bags. Swed J Agric Res, 12. $163-171$

18. Maiga HA, Schingoethe D.J, Henson JE (1996): Ruminal degradation. amino acid composition and intestinal didestibility of the residual components of five protein supplements. J Dairy Sci, 79. 1647-1653.

19. McAllister TA, Cheng K.J, Beauchemin KA, Bailey DRC, Pickard MD, Gilbert RP (1993): Use of lignosulfonate to decrease the rumen degradability of canola meal protein. Can J Anim Sci, 73, 211-215.

20). Michalet-Doreau B, Cerneau P (1991): Influence of foodstuff particle size on in silu degradation of nitrogen in the rumen. Anim Feed Sci Tcch, 35, 69-81.

21. Mir Z, Macleod GK, Buchanan-Smith JG, Grieve DG, Grovum WL (1984): Methods for protecting soybean and canola froteins from degradation in the rumen. Can $\mathrm{J}$ Anim Sci, 64, 853-865.
22. Neutze, SA, Smith RL, Forbes W A (1993): Appliculion of an inhibitor in vitro method for estimating rumen deg. radation of feed protein. Anim Feed Sci Tech. 40. 251-265

23. Nishimuta JF, Ely DG, Boling JA (1974): Ruminal bypass of dietan soybean protein treated with heat, formalin and tamic acid. J Anim Sci, 39. 952-957.

24. Ørskov ER, Hovell FD DeB, Mould F (1980): The use of the nylon bag technique for the evaluation of feedsuffs Tropical Anim Prod. 5. 195-213.

25. Ørskov ER, McDonald I (1979): The extimation of pro. tein degradabiling in the ramen from inculation me. asurements weighted according to rate of passatse. J Agt Sci Camb, 92. 499-503.

26. Ørskov ER, Mills CR, Robinson JJ (1980): The use of whole blood for the protection of organic materials from degradation in the rumen. P Nutr Soc. 39. 60A.

27. Peter AP, Hatfield EE, Owens FN, Garrigus US (1971) Effects of aldehyde treatments of soybean meal on in vitro ammonia release. solubility and lami performance. J Nutr 101, 605.

28. Sarıçiçek Z (1999): Bazt protein kạnaklarmun tannik usil ile muamelesinin in situ rumen parçalanabilirliği üzerine etkisi. OMÜ Zir Fatk Dorg, 14. 7-17.

29. Schmidt SP, Benevenga NJ, Jorgensen NA (1973) Lffects of formaldehyde, slyoxal or hexamethylenetetramine treatment of soybean meal on nitrogen utilization and growth in rats and in vitro rumen ammonia release. I Anim Sci, 37, 1238.

30. Stanford K, McAllister TA, Xu Z, Pickard M, Cheng KJ (1995): Compression of lignosulfonate treated canola meal and sogbean meal protein as rumen undegradable protein supplements for lambs. Can J Anim Sci, 75. 371377.

31. Tamminga $S$ (1979): Protein degradation in the forestomachs of the ruminants. J Anim Sci, 49, 1615-1630.

32. Thomas E, Trenkle $\Lambda$, Burroughs W (1979) Evaluation of protective agents applied to soybeai meal and fed it cattle. I. Laboratory measurements. J Anim Sci. 49. 1337 1345.

33. Thomas E, Trenkle $\Lambda$, Burroughs W (1979): Evaluation of protective agents applied to sovbear meal and fed to cattle. II. Feedlot trials. J Anim Sci, 49. 1346-1356.

34. Yalçın S, Önol AG, Şehu A, Kocaoğlu B, Onbaşılar $\mathbf{I}$ (1999): Tannik asit ile islem gören răgll whum küspelerinin sindirilme derecesi ve rumende parcalamma izel. likleri. TÜBITAK VHAG-Proje No:VHAG-102. Kesin Rapor. Ankara.

35. Yalçın S, Şehu A, Ergün A, Kaya İ (200(0)): Findık küspesinin formaldehit ve kan ile muamelesinin rumende parçalanma özellikleri ve etkin yikılabilirliği üzerine etkisi. In. tcrnational Animal Nutrition Congress 2(0)(0). 4-6 Scptcmber 20(0), lsparta-Turkey. Procecdings. 153-159.

36. Yalçın S, Şehu A, Karakaş F (1998): Ayşiçĕ̆ kiispesınin formaldehit ve kan ile muamelesinin ruinende parçalanma ozzellikleri ve etkin yikılabilirligi uzerine etkisi. Turk J Vet Anim Sci, 22, 5()3-50).

37. Yilmaz A (1997): Ruminant beslemede kullanlan bazi protein kaynağt yemlerin naylon torba teknigi ile parçalanabilirlik karakteristiklerinin incelenmesi üzerinde bir arasttrma. Yem Magazin. Aralık 1997. 5, 36-46.

\section{Yazısma adresi:}

Prof. Dr. Sakine Yalçin

Ankara Üniversitesi Veteriner Fakültesi

Hayvan Besleme ve Beslenme Hastaliklarl Anahilim Dall, Diskapı 06110. Ankara 